\title{
Cointegration of Economic growth and External balance in Colombia: 1963-2016
}

\author{
Baron Ortegon Brayan Alexander. \\ babarono@unal.edu.co
}

\begin{abstract}
In this paper is analyzed the relation between GDP growth and External balance in Colombia for the study period (1963-2016) by using a VECM. Supposing everything else unchanged, we conclude that Colombian external balance granger caused GDP growth and there was indeed a long run relation between both variables. This outcome helps to explain the Colombian GDP growth dynamics over the last fifty years and the impact of trade policy on economic growth.
\end{abstract}

\section{Keywords}

Economic growth; External balance; Trade balance; Colombia; VEC model.

JEL codes: F00, F14, F17, F43, F47.

\section{Resumen}

En este artículo se analiza la relación entre crecimiento económico y el saldo de la balanza comercial en Colombia para el periodo de estudio (1963-2016) usando un modelo VEC. Suponiendo todo lo demás constante, se concluye que el saldo de la balanza comercial causo en el sentido de Granger el crecimiento económico colombiano, por lo tanto, existe una relación de equilibrio en el largo plazo entre estas variables. Este resultado contribuye a explicar la dinámica del crecimiento económico colombiano de los últimos cincuenta años y el impacto de la política comercial sobre este. 


\section{Palabras claves}

Crecimiento económico; Saldo de la balanza comercial; Colombia; Modelo VEC.

JEL: F14, F17, F43.

\section{Resumo}

Este artigo analisa a relação entre o crescimento econômico e o saldo da balança comercial na Colômbia para o período de estudo (1963-2016) usando um modelo VEC. Assumindo tudo o mais constante, se conclui que o saldo da balança comercial ocasionado no sentido de Granger o crescimento econômico colombiano, portanto, há uma relação de equilíbrio no longo prazo entre essas variáveis. Esse resultado ajuda a explicar a dinâmica do crescimento econômico colombiano nos últimos cinquenta anos e o impacto da política comercial sobre ele.

\section{Palavras chaves}

Crescimento econômico; Saldo da balança comercial; Colômbia; Modelo VEC.

JEL: F14, F17, F43. 


\section{Introduction}

In most of the $\mathrm{XX}$ century, Colombian trade policy was aimed to promote economic growth through an increasing External balance and a pretty active intervention on exchange rate and trade markets. That policy was mainly grounded on Prebisch and CEPAL views of Latin American developing countries and their historical low trade terms regarding to developed countries as one of the main causes of their underdevelopment. In Colombia, this trade practices began to change since 1986 in Virgilio Barco’s presidential term. However, in 1990, President Gaviria's government started la Apertura económica that was a gradual process intended to achieve a greater trade openness and. This policy diminished trade tax in more than 20 per cent, reduce effective protection from 75 per cent to 21 per cent, etc. (Villar et al, 2015). The next four presidents continued this process, but since 2002, Uribe's term and his successor boosted it even more with the sign of more than ten Free trade agreements, including with the USA in 2012 and the EU (Urquijo, 2015). Besides, it is member of regional agreements in trade issues, such as la Alianza del Pacifico and CAN (Montoya et al, 2016).

To study the relation between GDP growth and External balance, in Colombia for the study period (1963-2016), the last fifty years, it is suitable an economic model for an open economy as Mundell-Fleming (Fleming, 1962). Supposing everything else unchanged, this model sets a positive relation between GDP and a positive External Balance (See equation 1.) The relation between GDP growth and External balance in the year $t$ depends upon value of External balance in year t-1. (See equation 2):

$$
\begin{gathered}
Y=\bar{C}+\bar{I}+\bar{G}+E B \text { (Equation 1) } \\
Y=E B \\
\text { GDP Growth }=\frac{\left(Y_{t}-Y_{t-1}\right)}{Y_{t-1}}=\frac{\left(E B_{t}-E B_{t-1}\right)}{E B_{t-1}} \\
\frac{\left(Y_{t}-Y_{t-1}\right)}{Y_{t-1}}=G D P \text { Growth }=\frac{E B_{t}}{E B_{t-1}}-1 \text { (Equation 2) }
\end{gathered}
$$


Based on equation 2, if External balance in year $\mathrm{t}$ is zero: $E B_{t}=0$, GDP growth is zero. The kind of relation between GDP growth (rate of growth) and External balance (level) in the year $\mathrm{t}$ is:

i. Positive if External balance in year $t$ and External balance in year $t-1$ are greater than zero or if both are lesser than zero: $\left(E B_{t}>0 \wedge E B_{t-1}>0\right) \vee\left(E B_{t}<\right.$ $\left.0 \wedge E B_{t-1}<0\right)$

ii. Negative if External balance in year $t$ is greater than zero and External balance in year $\mathrm{t}-1$ is letter than zero or another way around:

$$
\left(E B_{t}>0 \wedge E B_{t-1}<0\right) \vee\left(E B_{t}<0 \wedge E B_{t-1}>0\right)
$$

Since the kind of relation between GDP growth and External balance in year $t$ is not always the same, but also depends on External balance in year $\mathrm{t}-1$ and these latter ones could be actually positive, negative or even zero, it is hard to determine the kind of relation. A VAR model is useful, as in the case of the relation between GDP growth and External balance, it is not easy to distinguish or characterize the structure of relations between two or more variables (Novales, 2014). However, as External balance elasticity of GDP (in level) in year $t$ is unitary, we suppose as our initial hypothesis, that the relation between GDP growth (growth rate) and External balance (in level) was positive in Colombia, in the study period (1963-2016):

$$
\varepsilon_{Y, E B_{t}}=1=\frac{\left(\frac{Y_{t}-Y_{t-1}}{Y_{t-1}}\right)}{\left(\frac{E B_{t}-E B_{t-1}}{E B_{t-1}}\right)}
$$

In fact, $\varepsilon_{Y, E B_{t}}$ of Colombia was positive: 0.15 , but relatively inelastic, on average, in the study period. 


\section{Econometric analysis.}

\subsection{VAR Model}

An econometric analysis is done, intended to, clarify a bit more the relation between External balance and GDP growth. This is done through a special kind of VAR model (Vector auto regression) called VEC (Vector error correction) both make it possible to find the multiple linear relations among time series, but besides the latter provides information about long-run equilibrium between variables and how fast they come back to it, after short-run shocks (Novales, 2014).

Stock and Watson (2001) warn us, one of the main problems of VAR models is its interpretation, since identification problem normally arises; it is difficult to discern between correlation and causation. Solving that problem is not just a statistical issue, but it requires adding a theoretical framework, that in this work was already presented above.

According to EViews (2018), for the case of a two-time series system, one cointegrating equation between them $\left(y_{2 t}=\aleph_{1} y_{1 t}+c_{1}\right)$ and one lagged difference, the first equation of VEC model is:

$$
\Delta y_{1, t}=\alpha\left(y_{1, t-1}-\aleph_{11} y_{2, t-1}-c_{1}\right)+\aleph_{12} \Delta y_{1, t-1}+\aleph_{13} \Delta y_{2 t-1}+\mathrm{K}_{1}+\varepsilon_{1 t}
$$

\section{(Equation 3)}

where, $\Delta y_{1, t} \_1 \mathrm{t}$ is the first difference of the first endogenous variable; $y_{1, t-1}$ is the first endogenous variable with one lag; $\aleph_{11}$ is coefficient of the sole cointegration equation; $c_{1}$ is constant term of the sole cointegration equation; $\aleph_{12}$ is coefficient of coefficient error term of the first variable with one lag; $\aleph_{13}$ is coefficient of coefficient error term of the second variable with one lag; $\varepsilon_{1 t}$ are residues of the first equation of VEC model; $\mathrm{K}_{1}$ is constant term of the first equation of VEC model ; $\alpha$ is coefficient of the error correction term in long run equilibrium of the first variable, it must be $<0$ and measures speed of adjustment of the first variable towards long-run equilibrium (EViews, 2018). 
The second equation is analogous to the first one. Both series must satisfy the next conditions.

1. $y_{1 t}$ and $y_{2 t}$ are cointegrating processes of order 1: I (1):

2. $\varepsilon_{1 t}$ and $\varepsilon_{2 t}$ are white noise processes, which means that over time their expected values are constant, in this case equal to zero: $\mathrm{E}\left[\varepsilon_{1 t}\right]=0$ and $\mathrm{E}\left[\varepsilon_{2 t}\right]=0$; but also their variances are constant across time: $\sigma_{\varepsilon_{1 t}}^{2}=\mathrm{c}$ and $\sigma_{\varepsilon_{1 t}}^{2}=\mathrm{c}$, where c $\in R^{+}$, including zero.

3. $\operatorname{Cov}\left(\varepsilon_{1 t}, \varepsilon_{2 t}\right)=\sigma_{\varepsilon_{1 t} \varepsilon_{2 t}}$

\subsection{Graphical analysis}

Figure1. GDP growth (annual \%)

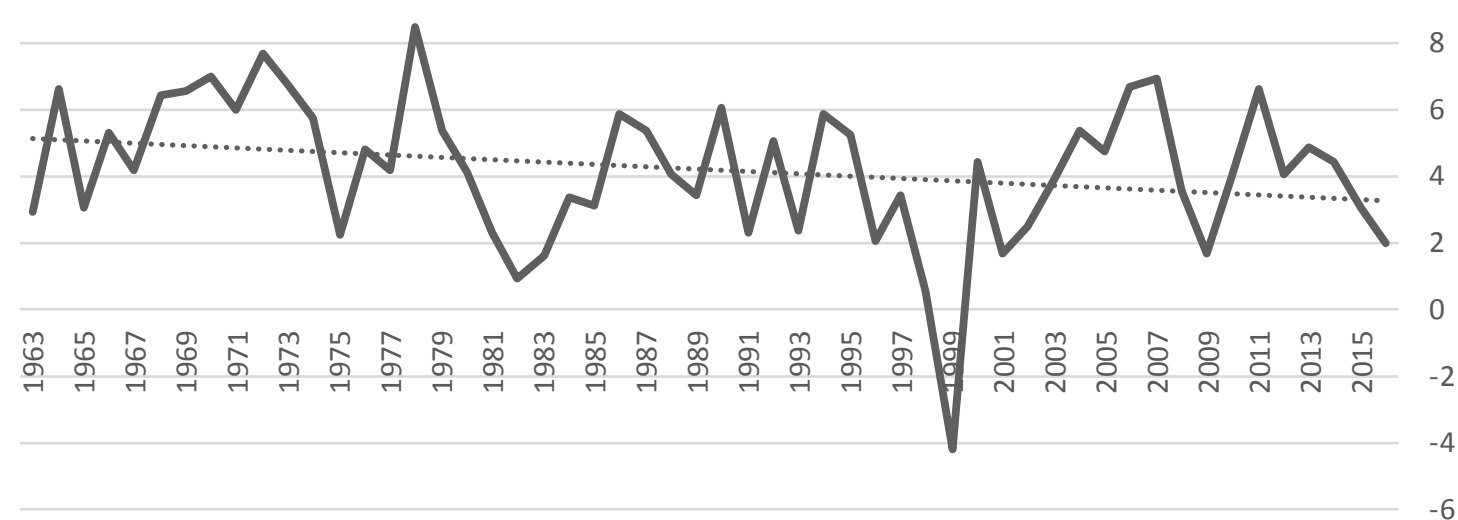

GDP growth (annual \%)

Source: Own construction based on the data provided by The World Bank database (2018). 
Figure2. External balance on goods and services (\% of GDP)

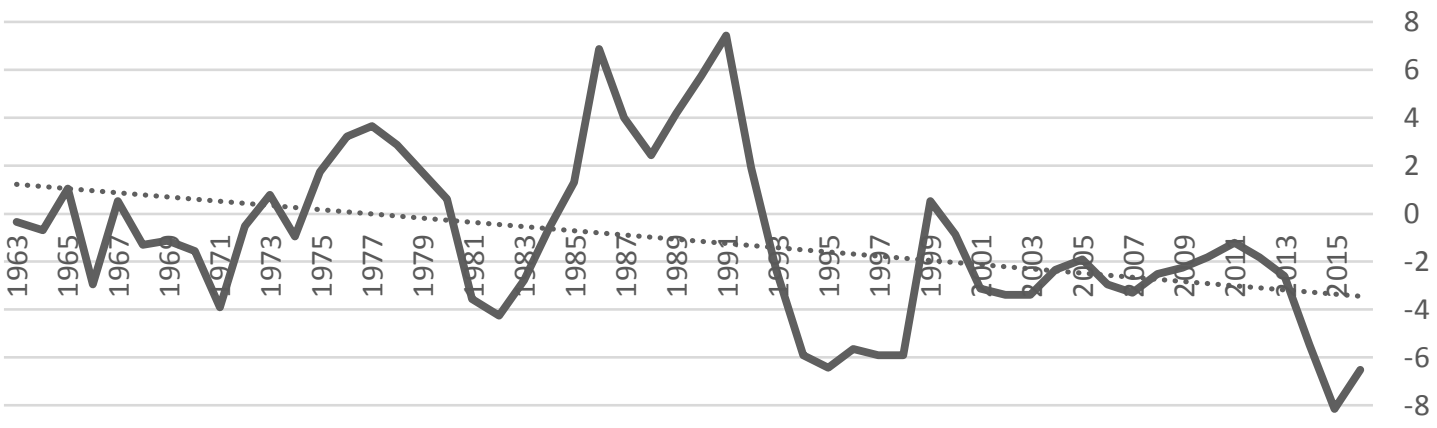

Based on Figure 1 and Figure 2, both series seem to have negative trends. These ones could be deterministic or stochastic. Applying Hodrick-Prescott filter (with a power of 2 and a lambda equals to 100) to both series to decompose and better observe their trends and cycle components, produces Figure 3 y Figure 4:

\section{Figure 3.}

Hodrick-Prescott Filter (lambda=100)

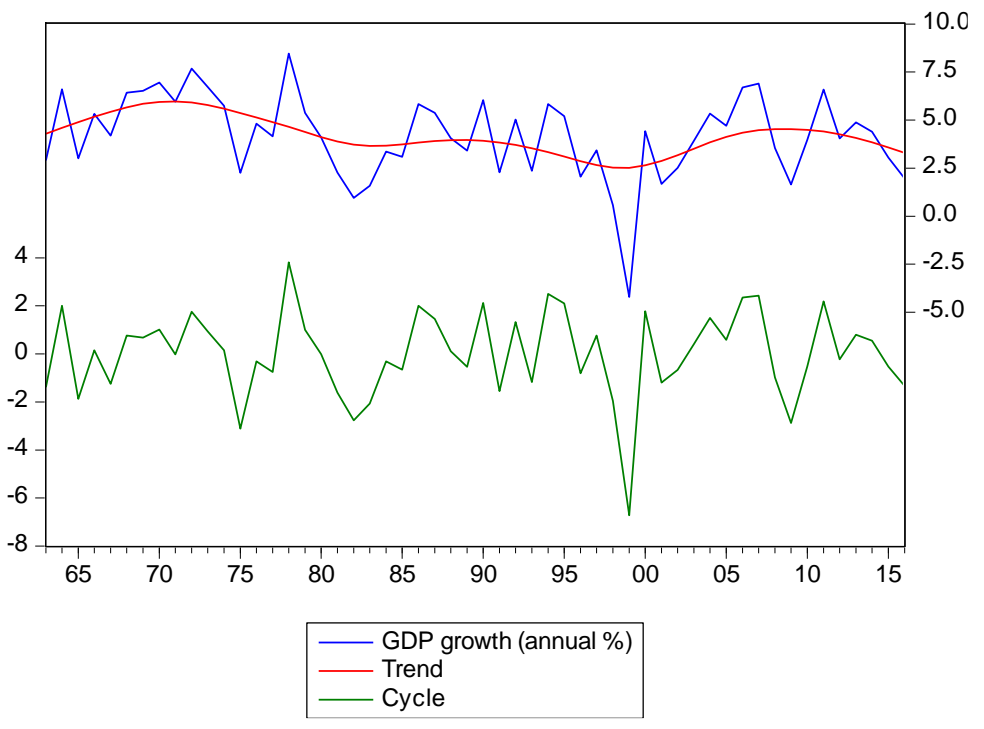

Source: World Bank (2018). Estimation made on EViews. 


\section{Figure 4.}

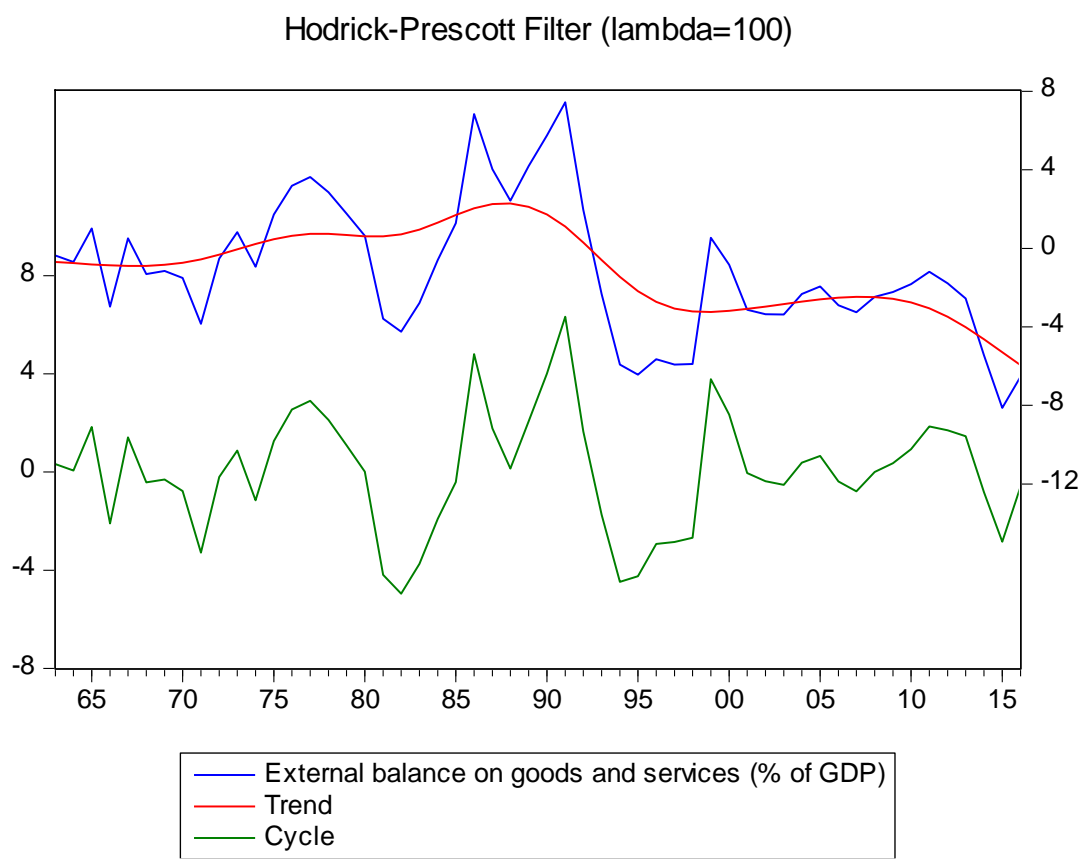

\section{Source: World Bank (2018). Estimation made on EViews.}

In this work, it is assumed that both trends are stochastic. In fact, most economic series also are it, thus it is a weaker assumption than deterministic trend one. Besides, for any amount of non-infinite data there is a deterministic trend and stochastic trend that fits the data equally well (Hamilton, 1994). A Stochastic trend mean involves nonstationarity (Hamilton, 1994).

\subsection{Unit root test}

According to Hamilton (1994), the ADF test (augmented Dickey-Fuller) contrasts the null hypothesis that the series has a unit root, which means that it is non-stationary. The alternative hypothesis asserts that the series does not have a unit root, consequently the series is stationary. Only in case of rejection of the null hypothesis at a level of significance: $\alpha$; it is possible to assert that there is significant statistical evidence to assert that the series is stationary and if so does, it is possible to use the VAR model, 
avoiding doing a spurious regression. In this work, the chosen significance level is: $\alpha=$ 0.05 .

In Figure 3, there is a clear tendency; therefore, we test stationery of this series by using Augmented Dickey Fuller (ADF) test including a trend and an intercept in the unit-root test. Specifying the test for a max of three lags to the GDP growth series, we get a pvalue $=0.0712$. Hence, at a significance level: $\alpha=0.05$, it can be said that there is significant statistically evidence, to state that the GDP growth series is non-stationary (See Annex 1).

In Figure 4, we test formally the stationery of this series by using Augmented Dickey Fuller (ADF) test including a trend and an intercept in the unit-root test. Specifying the test for a max of three lags to the External balance series, we get a p-value $=0.058$. Hence, at a significance level: $\alpha=0.05$, it can be said that there is significant statistically evidence, to state that the External balance series is non-stationary (See Annex 2).

\subsection{Integration order}

A non-stationary series $\left(y_{i t}\right)$ is integrating of order d: I (d) if it is necessary take $\mathrm{d}$ differences to make it stationary. In our case, if we take the first difference of each series: the GDP growth and the External balance series and apply ADF test with trend and intercept (three lags) at the 0.05 level, we get two new stationary series (See Annex 3 ), thus both the GDP growth and the External balance series are integrating of order 1: I (1). A VEC model with $\mathrm{k}$ endogenous variables should have $\mathrm{k}-1$ cointegrating relations (EViews, 2018).

\subsection{Akaike information criterion}

In order to select the optimal number of lags for our model VEC, it is suitable to use the Akaike information criterion (AIC), which estimates how much information a stochastic process provides in comparison to other ones (Novales, 2014), To get this criterion, it is necessary to run a VAR model, in spite of the fact that both series are non-stationary. The optimal number of lags in VEC models is one lesser than that VAR 
model. The AIC results that the most suitable VAR or that one which provides the most amount of information is a VAR model with two lags: VAR (2) (See Annex 4), therefore our VEC model should have an optimal number of lags equal to one: VEC (1).

\subsection{The cointegration test of Johansen}

The cointegration test of Johansen estimates whether a pair or more series are cointegrated one another or not. This test can have many null hypotheses; each one asserts that does not exist a determined cointegration level. In our case, given the fact that the both series have a stochastic trend, it must be tested by assuming that there is deterministic trend in data and the sole cointegrating equation has intercept and VAR test (EViews, 2018). The results of this tests does not reject the null hypotheses at the 0.05 level, consequently the model is cointegrated (See Annex 5.), which is ideal because it guarantees that the cointegration rank of differentiated series is not zero (Enders, 2003).

\subsection{Estimated VAR model}

After having checked that the series are non-stationary, have the same integrating order: I (1) and the optimal number of lags of VEC model, it is possible to run a VEC (1) model. Given the fact that both series have stochastic trend, the VEC model must be estimated without trend and with intercept in both Cointegrating equation and VAR (EViews, 2018) (See Annex 4.). The estimated VEC (1) model is:

$$
\begin{aligned}
& \Delta G D P \text { growt }_{1, t}=0.064\left(\text { External balance }_{t-1}-8.07 G D P \text { growt }_{t-1}-\right. \\
& 35.35)+0.24 \Delta \text { External balance }_{t-1}-0.14 \Delta G D P \text { growt }_{t-1}-0.052+\varepsilon_{1 t}
\end{aligned}
$$

\section{(Equation 4)}


$\Delta$ External balance $_{2, t}=0.002\left(\right.$ External balance $_{t-1}-8.07$ GDP growth $_{t-1}+$

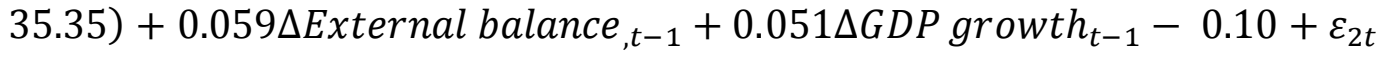

\section{(Equation 5)}

The sole estimated cointegrating equation is depicted in Figure 5.:

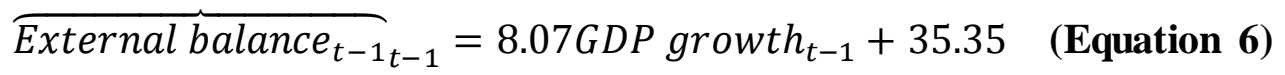

\section{Figure 5.}

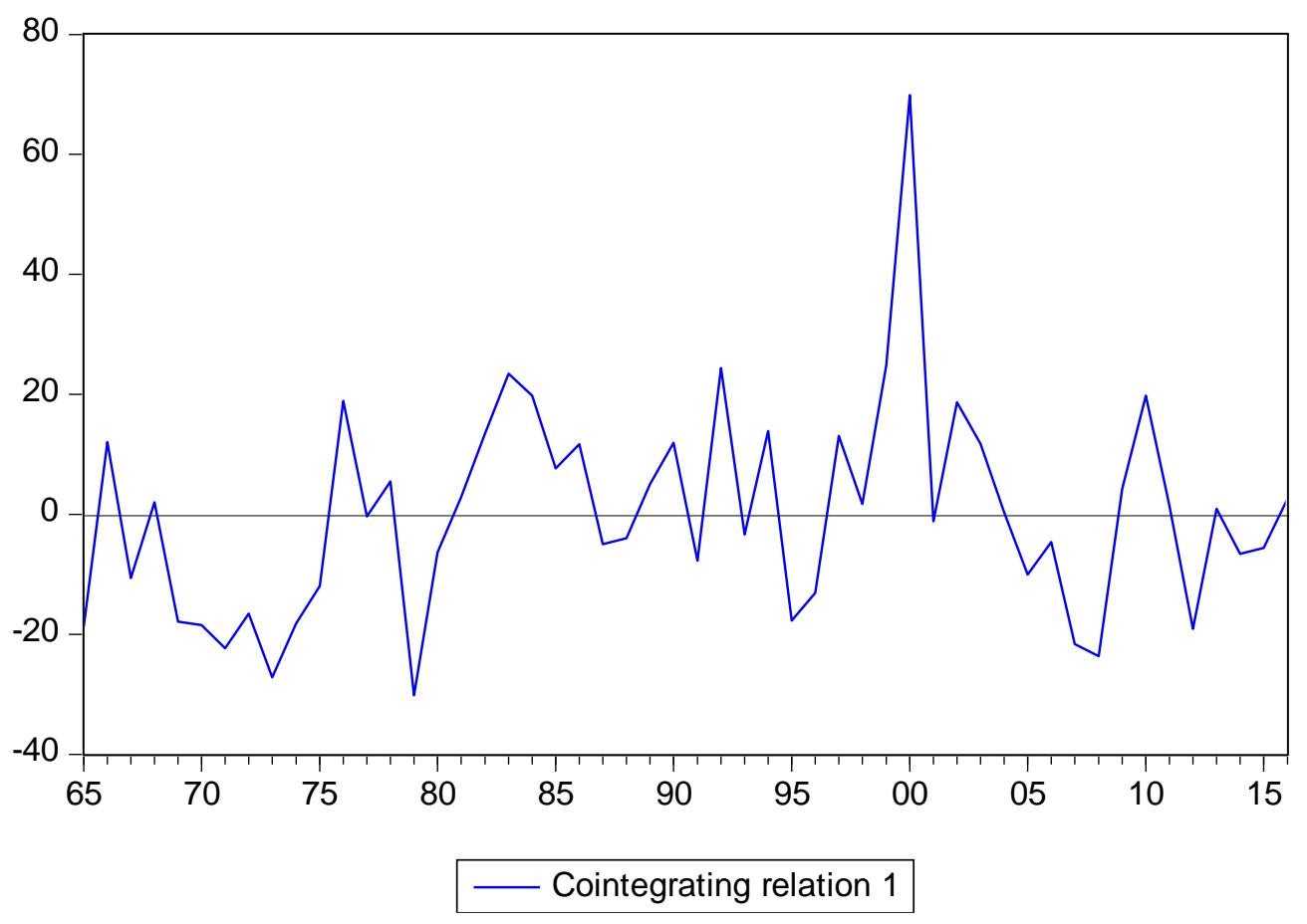

Source: World Bank (2018). Estimation made on EViews.

\section{Assumptions}

It is broadly known that in VAR models, parameters and $\mathrm{R}^{2}$ coefficient are not usually interpreted (Sosa, 2016). It must be checked that the estimated model is not a spurious regression, that is to say the series reflect a significant implicit relation between GDP 
growth and External balance, thus, it is necessary the accomplishment of some assumptions of VEC model and their statistical significance.

\subsection{Correlograms}

First, we see the correlograms of residuals of the equations of our model until 12 lags, in order to check that there is not autocorrelation among them (See Annex 6.). We find that in an equation appears to be autocorrelation of thirteen order, however other Autocorrelation tests discard this possibility. The VEC Portmanteau test for autocorrelations have as null hypothesis that there is not serial correlation for each lag. To verify the non-autocorrelation of residuals assumption, the VEC estimated model is tested, in our case up to twenty lags, resulting that the model fulfills this assumption in the Portmanteau tests, at a significance level: $\alpha=0.05$, (See Annex 7.). For the rest of lags, there is not any problem, thus this assumption is completely fulfilled.

\subsection{Stability of VEC model}

In order to verify the stability of the VEC model across the time, through the inverse roots of the characteristic AR polynomial test, it is vital to know that in a VEC model only k-r roots should be equal to unity, where $\mathrm{k}$ is the number of endogenous variables and $\mathrm{r}$ is the number of cointegrating relations (EViews, 2018). In the estimated VEC model k-r is equal to one. Testing roots of characteristic polynomial of the estimated VECM, at a significance level: $\alpha$ : 0.05 , this assumption is fulfilled, since only one root is equal to one (See Annex 8.).

An assumption of VEC model is that residuals are distributed normally. To verify it, we use VEC Residual Normality Tests (according to Orthogonalization: Cholesky (Lutkepohl) criterion), validating also the fulfillment of this assumption at a significance level: $\alpha=0.05$, (See Annex 9.). Regarding the assumption of homokedasticity of residuals, to verify it, it is used the white heteroskedasticity test with no cross terms and the white heteroskedasticity test with cross terms at a significance level: $\alpha=0.05$, the estimated VEC model also fulfills assumption of homokedasticity of residuals (See Annex 10.) 


\section{Granger causality}

In a spurious model the variables are inferred statistically as if they were causally correlated, but they are actually independent to each other. That kind of model is not desirable at all, in order to verify if it happens or not, it is necessary to perform the Granger Causality Test (Novales, 2014).

A variable $X_{t}$ causes in the sense of Granger to another $Y_{t}$, if, past values of $X_{t}:\left(X_{t-1}\right.$, $\mathrm{X}_{\mathrm{t}-2}$ and so forth)if $\mathrm{X}_{\mathrm{t}}$ is able to predict future values of $\mathrm{Y}_{\mathrm{t}}, \mathrm{Y}_{\mathrm{t}+1}, \mathrm{Y}_{\mathrm{t}+2}$ and so on). The Granger test tells us, if that predictive capacity of the past values of $\mathrm{X}_{\mathrm{t}}$ is statistically significant or not, at a level of significance $\alpha$ (Novales, 2014). The null hypothesis of the Granger test says: $X_{t}$ does not Granger cause $Y_{t}$. The alternative hypothesis of the Granger test says: $X_{t}$ does Granger cause $Y_{t}(\operatorname{Lin}, 2008)$. Therefore, running this test in the estimated VEC model will help to identify whether External balance granger caused the distribution of the GDP growth (See Table 1.):

\section{Table 1. VEC Granger causality test.}

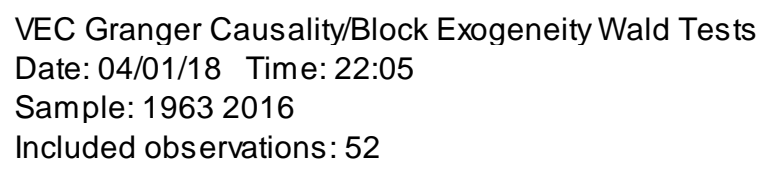

Dependent variable: D(EXTERNAL_BALANCE_ON_GOOD)

\begin{tabular}{cccc}
\hline \hline Excluded & Chi-sq & df & Prob. \\
\hline \hline D(GDP_GRO... & 0.099620 & 1 & 0.7523 \\
\hline \hline All & 0.099620 & 1 & 0.7523 \\
\hline \hline Dependent variable:D(GDP_GROWTH_ANNUAL__ & & \\
\hline \hline & & & \\
\hline \hline Excluded & Chi-sq & df & Prob. \\
\hline D(EXTERNAL... & 3.997039 & 1 & 0.0456 \\
\hline \hline All & 3.997039 & 1 & 0.0456 \\
\hline \hline
\end{tabular}

Data Source: World Bank (2018). Estimation made on EViews. 
On the one hand, as the p-value (0.7523) in the first regression is greater than the level of significance (0.05), it is possible to say that the first difference (Variations of year t1 to $t$ ) of GDP growth did not Granger cause the first difference of External balance, in the period 1963-2016. On the other hand, as the p-value (0.0456) of the second regression is less than the level of significance $(0.05)$, it is possible to say that the first

difference of External balance did Granger cause the first difference of GDP growth, in the period 2000-2014.

The interpretation of the results of the econometric model, especially Granger's causality test, is the following:

Variations in GDP growth did not explain in a temporary sense the External balance, in the study period.

Variations in the External balance did explain in a temporary sense the variations in the GDP growth, in other words, they explain, at least partially (in a temporary sense), the GDP growth.

\section{Impulse response functions.}

The residuals of the VEC model: $\varepsilon_{1 t}$ and $\varepsilon_{2 t}$ can be thought as deviations (impulses, random shocks or innovations) of each one of the endogenous variables from a perfect estimation (Stock \& Watson, 2001). The impulse response functions of the model express how the behavior of one endogenous variable changes against a simulated random shock (innovation) of the other variables' residuals or theirs. It is supposed that all other errors are equal to zero and that a particular error of the estimated VECM (random shock) returns to zero afterwards, in the long-run (Stock \& Watson, 2001). In this case, it is supposed responses up to 20 periods after the random shock and the decomposition method used is Cholesky (DOF adjusted), with innovations equal to one standard deviation: 
Figure 6. Impulse response functions.

\section{Response of EXTERNAL_BALANCE_ON_GOOD to Cholesky \\ One S.D. Innovations}

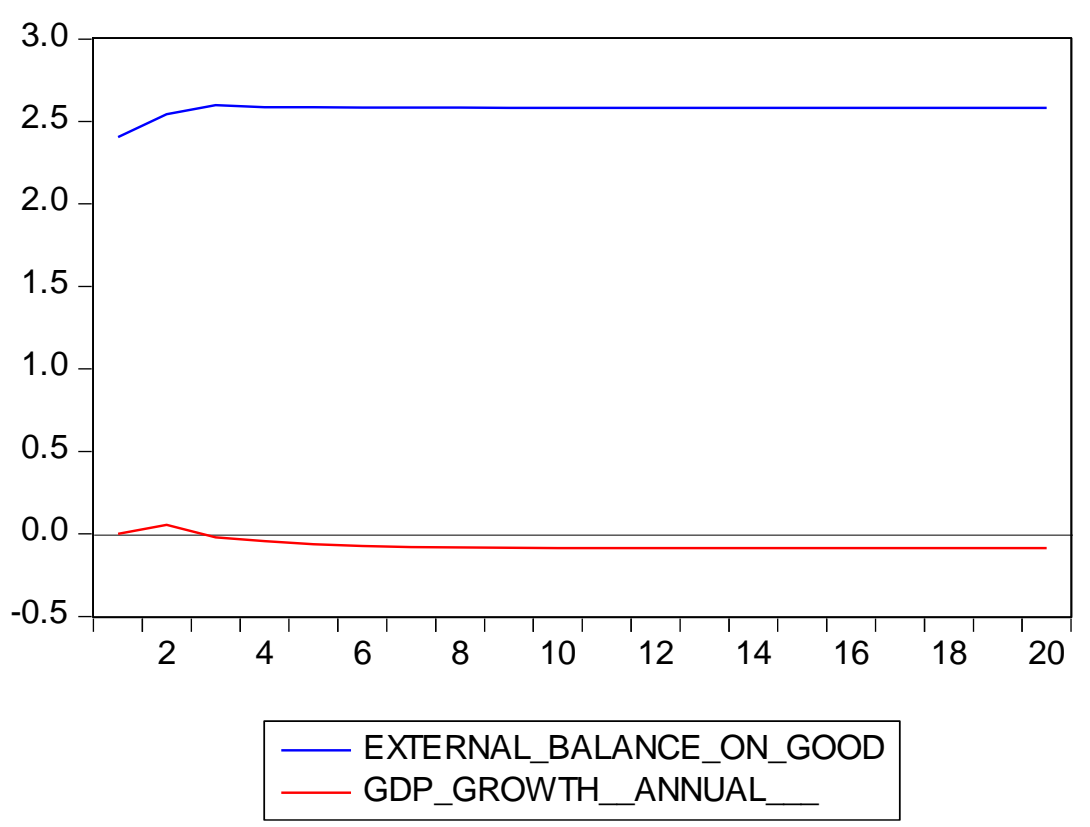

\section{Source: World Bank (2018). Estimation made on EViews.}

The Figure 6 shows the effect of an unexpected one standard deviation increase in the External balance (blue line) and the GDP growth (red line) on the External balance. The Figure 6 depicts as a shock or increase of External balance in one standard deviation increases the External balance, having a permanent effect on itself through the 20 periods, that is to say, the long-run. As for, the GDP growth, their innovations have a slight positive effect on External balance initially, but from third lag this effect changes and becomes a negative one, but its effect is too weak though. A random shock on External balance lasts up to twentieth-post-impulse period. In other words, innovations spread in the long run. 
Figure 7. Impulse response functions.
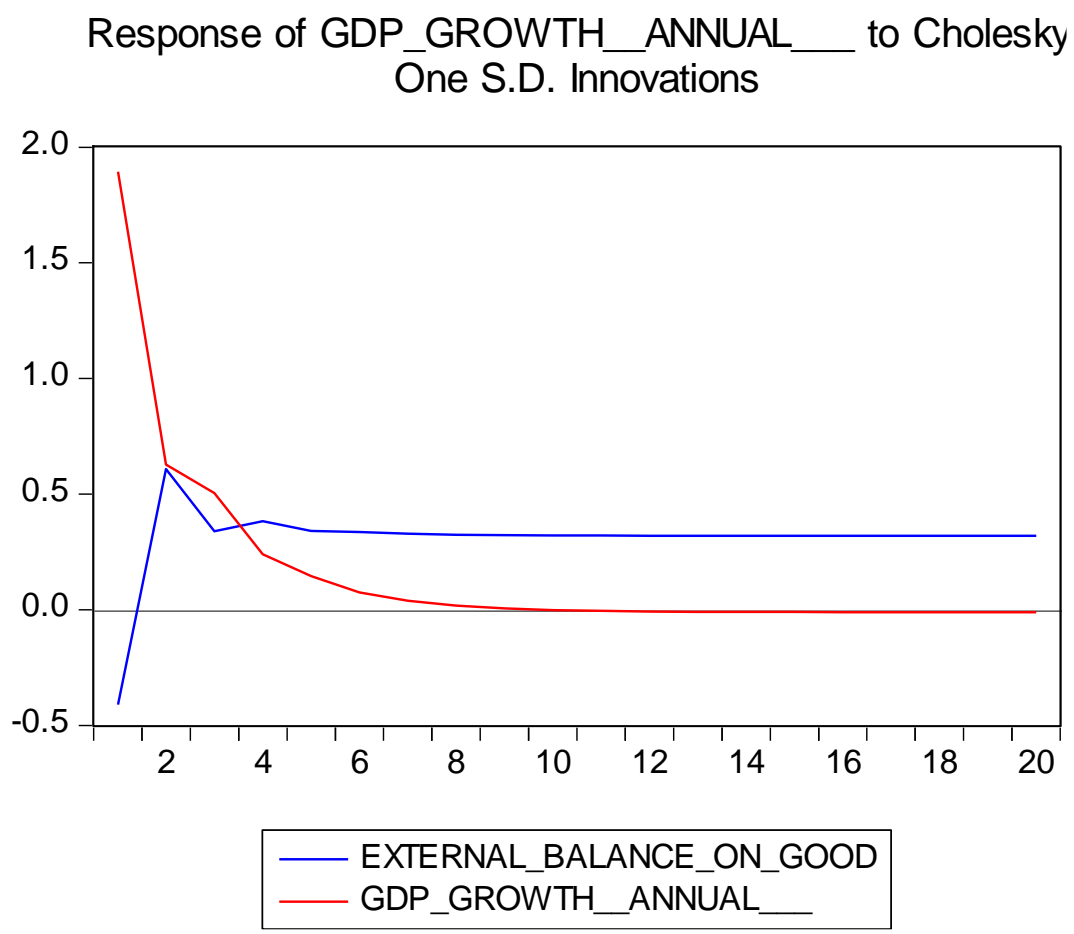

\section{Source: World Bank (2018). Estimation made on EViews.}

The Figure 7 shows the effect of an unexpected one standard deviation increase in The GDP growth (red line) and the External balance (blue line) on the GDP growth. As for, GDP growth, as expected its own innovations have a strong positive effect on GDP growth itself initially, which decrease abruptly from the second lag but keeps on being positive up to the seventh period, from where begins to wane and becomes almost nil, in other words has an effect in medium-run. On the other hand, initially, an innovation of the External balance increases mildly GDP growth, but having a permanent effect through the 20 periods though, that is to say, a random shock of External balance lasts up to twentieth-post-impulse period. Put simply, innovations of the External balance on the GDP growth spread in the long run. 


\section{Variance Decomposition}

According to Novales (2014), Variance decomposition helps to provide an estimation of size of prediction error of each variable, in terms of each of other variables. Errors inevitably increase with prediction horizon. It is, therefore, a way of making inference about the intertemporal relations between the variables that compose VEC model. The components of each variance are expressed in percentage terms (See Figure 8 and Figure 9.).

\section{Figure 8}

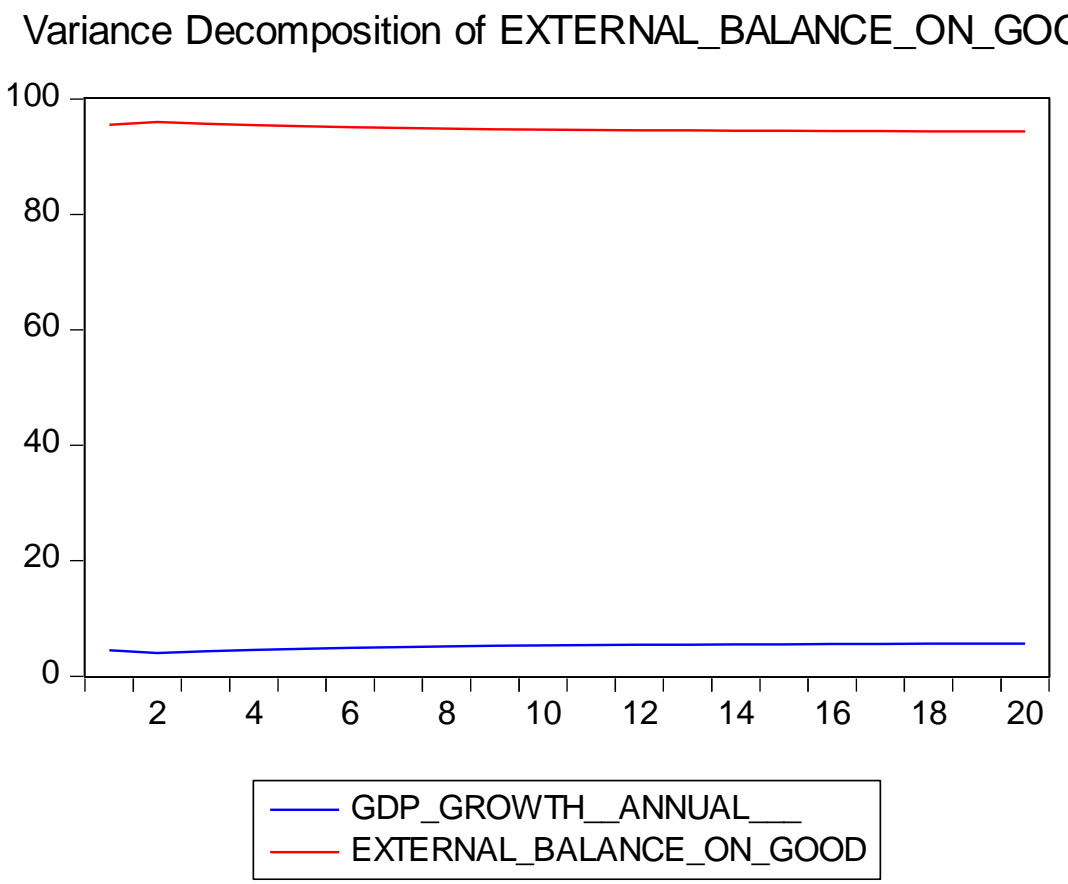

Source: World Bank (2018). Estimation made on EViews.

The estimated variance for the variable the External balance (See Figure 8.) is almost explained entirely (95 per cent) by their own shock over all the lag period. The other percentage (roughly 5 per cent) of variance depends on the GDP growth 


\section{Figure 9.}

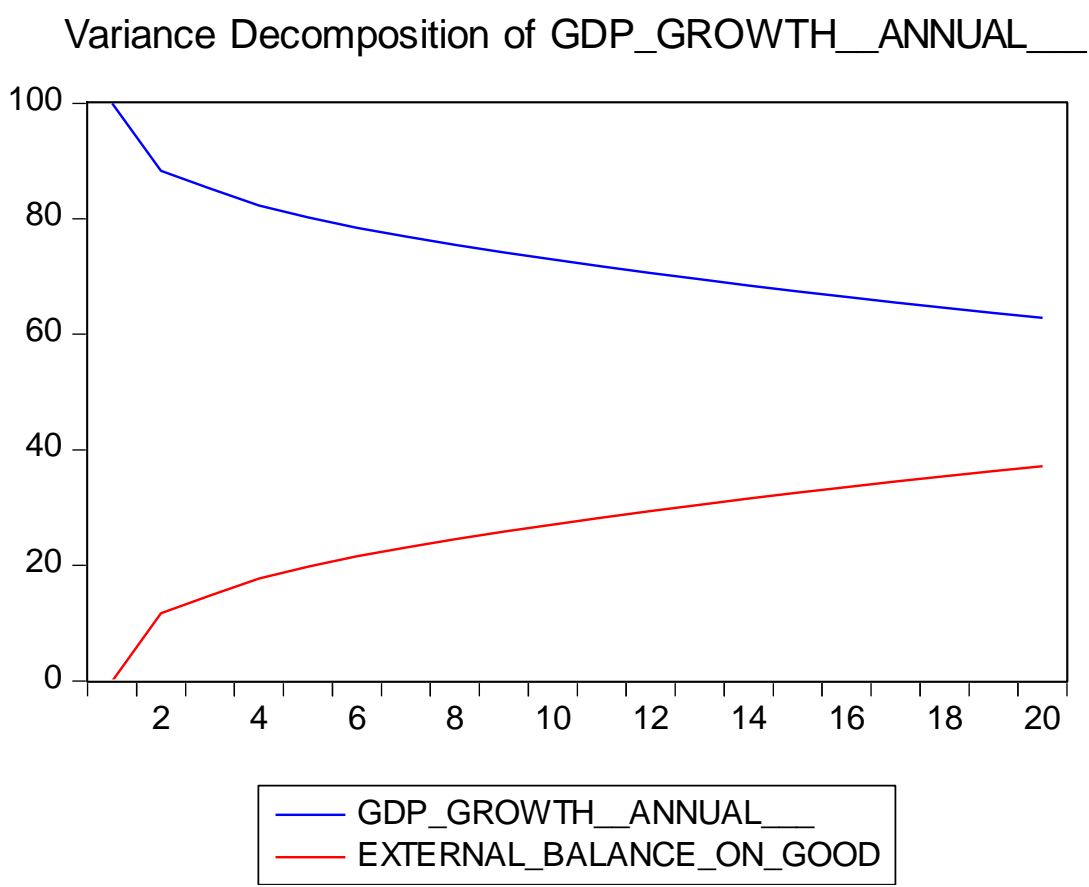

\section{Source: World Bank (2018). Estimation made on EViews.}

As far as the GDP growth is concerned, the contribution of variables, to the variance of the GDP growth changes over time (See Figure 8.), so that, after the fifth lag, about 20 per cent of its variance is explained by the External balance. This percentage skyrocketed up to 37 per cent in the twentieth period. On average, the External balance explains 30 per cent of the variance of the GDP growth. Up to the other 70 per cent, on average, of its own variance is explained by the variable itself: the GDP growth.

\section{Forecasting}

Applying a dynamic forecast to the estimated model for the sample period: 1963-2016 and by including actual values for the sample observations and the coefficient of uncertainty of standard errors (to reduce the largest source of forecast error, as the 
forecast residuals are not known), a set of forecast values are made for both of the series:

Figure 10. Forecasting of GDP growth and External balance.
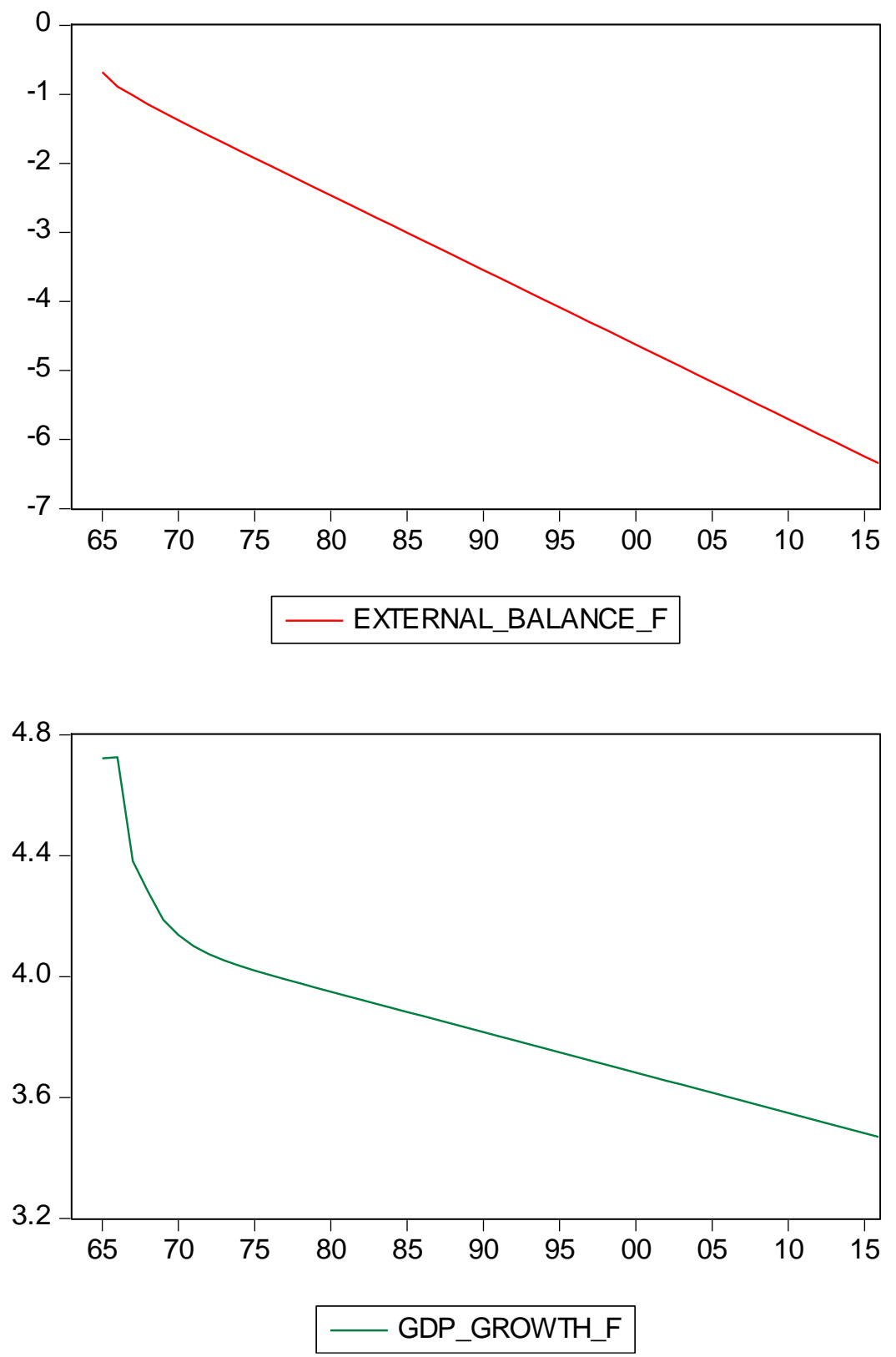

Source: World Bank. Estimation made on EViews.

Some indicators such as: RMSE, MAE, MAPE and Theil index; which are pretty helpful to evaluate the suitability of the estimated model. A simple guideline to grasp 
the meaning of these measures is the lower values are, the better forecasts the model produces (Woschnagg \& Cipan, 2004):

\section{Table 2. Forecasting evaluation.}

\begin{tabular}{|c|c|c|c|c|c|}
\hline \multicolumn{6}{|c|}{$\begin{array}{l}\text { Forecast Evaluation } \\
\text { Date: 04/02/18 Time: 04:00 } \\
\text { Sample: } 19632016 \\
\text { Included observations: } 54 \\
\end{array}$} \\
\hline Variable & Inc. obs. & RMSE & MAE & MAPE & Theil \\
\hline D(GDP_GROWT... & 54 & 4.589709 & 3.722005 & 115.0524 & 0.715251 \\
\hline D(EXTERNAL_B... & 54 & 4.588735 & 4.126745 & 107.6534 & 0.743162 \\
\hline
\end{tabular}

RMSE: Root Mean Square Error

MAE: Mean Absolute Error

MAPE: Mean Absolute Percentage Error

Theil: Theil inequality coefficient

\section{Source: World Bank. Estimation made on EViews.}

Theil index is a good benchmark to help gauge results. The closer Theil inequality coefficients are to 1 , the lesser ability to forecast the model has. On the other hand, the closer Theil inequality coefficients are to 0 , the greater ability to forecast the model has (Woschnagg \& Cipan, 2004). In the estimated VEC model case (See Table 2.), the Theil index of The GDP growth is 0.71 , (Equation (4)), that means that fifth equation's ability is far better forecast than the estimated equation for the External balance (Equation 5), whose Theil index is a bit higher 0.74 .

The impulse response functions, the variance decomposition analysis and the forecasting process suggest that External balance had a role in the dynamics of the GDP growth in the long-run. In the estimated VEC model, External balance's random shocks have positive impacts in increasing GDP growth of the first quintile, but of mild intensity though.

As has been said at the beginning of this paper, GDP growth depends not only on External balance, but also on other aggregate variables such as consume, investment and public expenditure. They have not been taken them into account in the econometric model, mainly because the purpose of this work is to analyze only the relation between 
GDP growth and External balance. Furthermore, by not taking into account these variables, the model VECM avoids losing degrees of freedom (n-k; $\mathrm{k}$ is the number of parameters) to the most. By doing so, we make the estimated model as parsimonious as possible.

\section{Discussion and conclusions:}

Now, we are able to answer the fundamental question, with which this work started: What was the relation between GDP growth and External balance in Colombia, in the long run, during the period: 1963-2016? The econometric analysis helped to determine the validity of our initial hypothesis, in the period 1963-2016, the GDP growth, and the External balance had a positive relation in the long-run. After that, it was checked out that the External balance did Granger cause the GDP growth, this entails that during the study period, there was a direct and a causal relation (in a temporary sense) between External balance and GDP growth, but its effect was mild, though.

Given the fact, that the definition of External balance, according to the World Bank is difference between Exports of goods and services minus Imports of goods and services (World Bank, 2018). A change of sign of the average of the External balance involves an external deficit on average, and therefore as the External Balance Granger causes GDP growth, an average external deficit must have a negative impact on the economic growth. What joint with the external balance Elasticity of GDP, the estimated impulse response analysis and the granger casualty test, support the validity of our initial hypothesis,

A positive External balance or a trade surplus could boost economic growth, through several ways, for example an increase of exports, better terms of trade, a decrease of imports, or a rise of productivity of factors in export sectors that rises their income shares, (Casas \& Guzman, 2015). Actually, External balance depends, at least partially, on foreign GDP, through demand of exports, but also depends on local GDP, negatively at least partially, through demand of imports (Oliveros \& Huertas, 2015) and in turn 
local GDP depends positively of imports, since a percentage of imports is used as input in local production, etc. That's why having chosen a VAR model was a suitable option, since it deals with both External balance and GDP growth as endogenous variables, helping us to deal with problems of endogeneity, at least empirically. In the study period, in Colombia, External balance caused in a temporary sense to GDP growth, and not another way around.

\section{References.}

Casas, E. A. M., \& Guzmán, J. F. (2015). El deterioro de los términos de intercambio: Teoría y evidencia empírica para Colombia 1980-2010. Revista Mundo Económico y Empresarial, (10).

Enders, W. (2003). Applied Econometric Time Series. John Wiley \& Sons.

EViews 10 Help Topics. (2018). Retrieved from: http://www.eviews.com/help

Fleming, J. M. (1962). Domestic financial policies under fixed and under floating exchange rates. Staff Papers, 9(3), 369-380.

González, J. T. (2014). Colombia: logros en dos decadas de modelo de desarrollo aperturista-analisis según resultados de balanza comercial. Análisis Político, 27(82), 212.

Hamilton, J. D. (1994). Time series analysis (Vol. 2). Princeton: Princeton university press. 
Lin, J. (2008). Notes on testing causality. Institute of Economics, Academia Sinica, Department of Economics, National Chengchi University.

Montoya-Uribe, D. A., Gonzalez-Parias, C. H., \& Duarte-Herrera, L. K. (2016). Situación y retos de Colombia en materia de comercio exterior, en el marco de la Alianza del Pacífico. Entramado, 12(1), 50-65.

Novales, A. (2014). Modelos vectoriales autoregresivos (VAR).

Oliveros, H., \& Huertas-Campos, C. A. (2015). Desequilibrios nominales y reales del tipo de cambio en Colombia. Artículos de revista.

Sosa, W. (2006). Vectores autoregresivos (VAR), curso del Banco central de Chile: Vectores Autorregresivos para Datos en Paneles. Retrieved on November 21 of 2016 from: http://faculty.udesa.edu.ar/WalterSosa/PVAR/bcchile2.pdf

Stock, J. H., \& Watson, M. W. (2001). Vector autoregressions. The Journal of Economic Perspectives, 15(4), 101-115.

The World Bank. (2018). Database: World Development Indicators. Retrieved from http://databank. worldbank.org/data/reports.aspx?source=2\&country=COL\#

Urquijo, P. (2015). Análisis de la implementación del Tratado de Libre Comercio entre Estados Unidos y Colombia (Master's thesis, Universidad Militar Nueva Granada). 
Villar, L., Romero, J. V., \& Pabón, C. (2015). Política cambiaria, monetaria y fiscal: ¿ha aprendido Colombia a mitigar los efectos de las crisis?

Woschnagg, E \& Cipan, J. (2004). Evaluating forecast accuracy. University of Vienna, Department of Economics. 


\section{Annex 1.}

Null Hypothesis: GDP_GROWTH_ANNUAL has a unit root

E $\overline{x o g}$ enous: Constant, Linear Trend

Lag Length: 3 (Fixed)

\begin{tabular}{llll}
\hline \hline & & t-Statistic & Prob. $^{*}$ \\
\hline \hline Augmented Dickey-Fuller test statistic & & -3.342354 & 0.0712 \\
\hline Test critical values: & $1 \%$ level & -4.152511 & \\
& $5 \%$ level & -3.502373 & \\
& $10 \%$ level & -3.180699 & \\
\hline \hline
\end{tabular}

*MacKinnon (1996) one-sided p-values.

Augmented Dickey-Fuller Test Equation

Dependent Variable: D(GDP_GROWTH_ANNUAL__ )

Method: Least Squares

Date: 04/01/18 Time: 13:44

Sample (adjusted): 19672016

Included observations: 50 after adjustments

\begin{tabular}{lrlll}
\hline \hline \multicolumn{1}{c}{ Variable } & Coefficient & Std. Error & t-Statistic & Prob. \\
\hline \hline GDP_GROWTH_ANNUAL_(-1) & -0.723303 & 0.216405 & -3.342354 & 0.0017 \\
D(GDP_GROWTH_ANNUAL__(-1.. & 0.017742 & 0.200614 & 0.088439 & 0.9299 \\
D(GDP_GROWTH_ANNUAL_(-2... & 0.168121 & 0.183881 & 0.914291 & 0.3655 \\
D(GDP_GROWTH_ANNUAL_(-3... & 0.111574 & 0.146239 & 0.762955 & 0.4496 \\
& 3.895373 & 1.323196 & 2.943913 & 0.0052 \\
\multicolumn{1}{c}{ @_TREND("1963") } & -0.031587 & 0.022083 & -1.430361 & 0.1597 \\
\hline \hline & & & & \\
R-squared & 0.355368 & Mean dependent var & -0.067246 \\
Adjusted R-squared & 0.282115 & S.D. dependent var & 2.470879 \\
S.E. of regression & 2.093529 & Akaike info criterion & 4.427746 \\
Sum squared resid & 192.8460 & Schwarz criterion & 4.657189 \\
Log likelihood & -104.6936 & Hannan-Quinn criter. & 4.515119 \\
F-statistic & 4.851209 & Durbin-Watson stat & 2.015095 \\
Prob(F-statistic) & 0.001280 & & & \\
\hline
\end{tabular}




\section{Annex 2.}

Null Hypothesis: EXTERNAL_BALANCE_ON_GOOD has a unit root Exogenous: Constant, Linear Trend Lag Length: 3 (Fixed)

\begin{tabular}{llcc}
\hline \hline & & t-Statistic & Prob. $^{*}$ \\
\hline \hline Augmented Dickey-Fuller test statistic & & -3.432895 & 0.0584 \\
\hline Test critical values: & $1 \%$ level & -4.152511 & \\
& $5 \%$ level & -3.502373 & \\
& $10 \%$ level & -3.180699 & \\
\hline \hline
\end{tabular}

*MacKinnon (1996) one-sided p-values.

Augmented Dickey-Fuller Test Equation Dependent Variable: D(EXTERNAL_BALANCE_ON_GOOD) Method: Least Squares

Date: 04/01/18 Time: 13:46

Sample (adjusted): 19672016

Included observations: 50 after adjustments

\begin{tabular}{lrlll}
\hline \hline \multicolumn{1}{c}{ Variable } & Coefficient & Std. Error & t-Statistic & Prob. \\
\hline \hline EXTERNAL_BALANCE_ON_GOOD(-1) & -0.429597 & 0.125141 & -3.432895 & 0.0013 \\
D(EXTERNAL_BALANCE_ON_GOOD(-1... & 0.309175 & 0.145867 & 2.119559 & 0.0397 \\
D(EXTERNAL_BALANCE_ON_GOOD(-2... & 0.150008 & 0.145772 & 1.029053 & 0.3091 \\
D(EXTERNAL_BALANCE_ON_GOOD(-3... & 0.139609 & 0.145994 & 0.956266 & 0.3442 \\
C & 0.978733 & 0.686201 & 1.426306 & 0.1608 \\
\multicolumn{1}{c}{ @TREND("1963") } & -0.050029 & 0.023005 & -2.174648 & 0.0351 \\
\hline \hline & 0.235292 & Mean dependent var & -0.071439 \\
R-squared & 0.148393 & S.D. dependent var & 2.307950 \\
Adjusted R-squared & 2.129835 & Akaike info criterion & 4.462132 \\
S.E. of regression & 199.5926 & Schwarz criterion & 4.691575 \\
Sum squared resid & -105.5533 & Hannan-Quinn criter. & 4.549506 \\
Log likelihood & 2.707661 & Durbin-Watson stat & 1.846787 \\
F-statistic & 0.032253 & & \\
Prob(F-statistic) & \multicolumn{4}{l}{} \\
\hline
\end{tabular}




\section{Annex 3.}

Null Hypothesis: D(GDP_GROWTH_ANNUAL__ ) has a unit root Exogenous: Constant, Linear Trend Lag Length: 3 (Fixed)

\begin{tabular}{llll}
\hline \hline & & t-Statistic & Prob. $^{*}$ \\
\hline \hline Augmented Dickey-Fuller test statistic & & -4.395403 & 0.0052 \\
\hline Test critical values: & $1 \%$ level & -4.156734 & \\
& $5 \%$ level & -3.504330 & \\
& $10 \%$ level & -3.181826 & \\
\hline \hline
\end{tabular}

*MacKinnon (1996) one-sided p-values.

Augmented Dickey-Fuller Test Equation Dependent Variable: D(GDP_GROWTH_ANNUAL__,2)

Method: Least Squares

Date: 04/01/18 Time: 16:20

Sample (adjusted): 19682016

Included observations: 49 after adjustments

\begin{tabular}{|c|c|c|c|c|}
\hline Variable & Coefficient & Std. Error & $\mathrm{t}$-Statistic & Prob. \\
\hline D(GDP_GROWTH_ANNUAL__(-1)) & -1.962626 & 0.446518 & -4.395403 & 0.0001 \\
\hline D(GDP_GROWTH_ANNUAL_ $(-1), \ldots$ & 0.473417 & 0.372826 & 1.269806 & 0.2110 \\
\hline $\mathrm{D}(\mathrm{GDP}$ GROWTH ANNUAL $(-2), \ldots$ & 0.253027 & 0.273047 & 0.926679 & 0.3593 \\
\hline D(GDP GROWTH ANNUAL $(-3), \ldots$ & 0.098387 & 0.148521 & 0.662442 & 0.5112 \\
\hline $\bar{C}$ & 0.093470 & 0.769448 & 0.121477 & 0.9039 \\
\hline @TREND("1963") & -0.005469 & 0.023846 & -0.229364 & 0.8197 \\
\hline R-squared & 0.713506 & \multicolumn{2}{|c|}{ Mean dependent var } & 0.000812 \\
\hline Adjusted R-squared & 0.680192 & \multicolumn{2}{|c|}{ S.D. dependent var } & 4.170615 \\
\hline S.E. of regression & 2.358547 & \multicolumn{2}{|c|}{ Akaike info criterion } & 4.668247 \\
\hline Sum squared resid & 239.1980 & \multicolumn{2}{|c|}{ Schwarz criterion } & 4.899898 \\
\hline Log likelihood & -108.3720 & \multirow{2}{*}{\multicolumn{2}{|c|}{$\begin{array}{l}\text { Hannan-Quinn criter. } \\
\text { Durbin-Watson stat }\end{array}$}} & 4.756135 \\
\hline F-statistic & 21.41804 & & & 2.029380 \\
\hline Prob(F-statistic) & 0.000000 & & & \\
\hline
\end{tabular}


Null Hypothesis: D(EXTERNAL_BALANCE_ON_GOOD) has a unit root Exogenous: Constant, Linear Trend

Lag Length: 3 (Fixed)

\begin{tabular}{llcc}
\hline \hline & & t-Statistic & Prob. $^{*}$ \\
\hline \hline Augmented Dickey-Fuller test statistic & & -4.284780 & 0.0071 \\
\hline Test critical values: & $1 \%$ level & -4.156734 & \\
& $5 \%$ level & -3.504330 & \\
& $10 \%$ level & -3.181826 & \\
\hline \hline
\end{tabular}

*MacKinnon (1996) one-sided p-values.

Augmented Dickey-Fuller Test Equation

Dependent Variable: D(EXTERNAL_BALANCE_ON_GOOD,2)

Method: Least Squares

Date: 04/01/18 Time: 16:21

Sample (adjusted): 19682016

Included observations: 49 after adjustments

\begin{tabular}{|c|c|c|c|c|}
\hline Variable & Coefficient & Std. Error & t-Statistic & Prob. \\
\hline D(EXTERNAL_BALANCE_ON_GOOD(-1)) & -1.224640 & 0.285812 & -4.284780 & 0.0001 \\
\hline 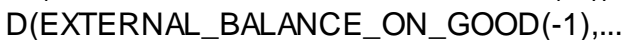 & 0.357315 & 0.243285 & 1.468709 & 0.1492 \\
\hline D(EXTERNAL_BALANCE_ON_GOOD(-2),... & 0.246304 & 0.198485 & 1.240918 & 0.2214 \\
\hline D(EXTERNAL_BALANCE_ON_GOOD $(-3), \ldots$ & 0.189125 & 0.143424 & 1.318641 & 0.1943 \\
\hline C & 0.077278 & 0.756744 & 0.102119 & 0.9191 \\
\hline @TREND("1963") & -0.007913 & 0.023574 & -0.335659 & 0.7388 \\
\hline R-squared & 0.469380 & \multicolumn{2}{|c|}{ Mean dependent var } & -0.038569 \\
\hline Adjusted R-squared & 0.407680 & \multicolumn{2}{|c|}{ S.D. dependent var } & 2.998564 \\
\hline S.E. of regression & 2.307764 & \multicolumn{2}{|c|}{ Akaike info criterion } & 4.624713 \\
\hline Sum squared resid & 229.0083 & \multicolumn{2}{|c|}{ Schwarz criterion } & 4.856364 \\
\hline Log likelihood & -107.3055 & \multirow{2}{*}{\multicolumn{2}{|c|}{$\begin{array}{l}\text { Hannan-Quinn criter. } \\
\text { Durbin-Watson stat }\end{array}$}} & 4.712601 \\
\hline F-statistic & 7.607464 & & & 1.856849 \\
\hline Prob(F-statistic) & 0.000034 & \multicolumn{2}{|c|}{ Durbin-Wats on stat } & \\
\hline
\end{tabular}




\section{Annex 4.}

VAR Lag Order Selection Criteria

Endogenous variables: EXTERNAL_BALANCE_ON_GOOD GDP_GROWTH_ANNUAL

Exogenous variables: $\mathrm{C}$

Date: 04/01/18 Time: 14:39

Sample: 19632016

Included observations: 49

\begin{tabular}{ccccccc}
\hline \hline Lag & LogL & LR & FPE & AIC & SC & HQ \\
\hline \hline 0 & -239.4846 & NA & 65.41621 & 9.856513 & 9.933730 & 9.885809 \\
1 & -209.1328 & $56.98691^{*}$ & 22.32004 & 8.780932 & $9.012584^{*}$ & $8.868821^{*}$ \\
2 & -204.5973 & 8.145554 & $21.86184^{*}$ & $8.759071^{*}$ & 9.145157 & 8.905552 \\
3 & -203.5856 & 1.734236 & 24.75994 & 8.881045 & 9.421565 & 9.086118 \\
4 & -203.0629 & 0.853407 & 28.66436 & 9.022976 & 9.717930 & 9.286640 \\
5 & -201.9250 & 1.764882 & 32.44674 & 9.139797 & 9.989185 & 9.462053 \\
\hline \hline
\end{tabular}

* indicates lag order selected by the criterion

LR: sequential modified LR test statistic (each test at $5 \%$ level)

FPE: Final prediction error

AIC: Akaike information criterion

SC: Schwarz information criterion

HQ: Hannan-Quinn information criterion 


\section{Annex 5}

Date: 04/01/18 Time: 16:28

Sample (adjusted): 19652016

Included observations: 52 after adjustments

Trend assumption: Linear deterministic trend

Series: EXTERNAL_BALANCE_ON_GOOD GDP_GROWTH_ANNUAL

Lags interval (in first differences): 1 to 1

Unrestricted Cointegration Rank Test (Trace)

\begin{tabular}{|c|c|c|c|c|}
\hline $\begin{array}{c}\text { Hypothesized } \\
\text { No. of CE(s) }\end{array}$ & Eigenvalue & $\begin{array}{l}\text { Trace } \\
\text { Statistic }\end{array}$ & $\begin{array}{c}0.05 \\
\text { Critical Value }\end{array}$ & Prob. ${ }^{* *}$ \\
\hline None * & 0.192052 & 18.58335 & 15.49471 & 0.0166 \\
\hline At most 1 * & 0.134212 & 7.493971 & 3.841466 & 0.0062 \\
\hline \multicolumn{5}{|c|}{$\begin{array}{l}\text { Trace test indicates } 2 \text { cointegrating eqn(s) at the } 0.05 \text { level } \\
{ }^{*} \text { denotes rejection of the hypothesis at the } 0.05 \text { level } \\
{ }^{* *} \text { MacKinnon-Haug-Michelis (1999) p-values }\end{array}$} \\
\hline \multicolumn{5}{|c|}{ Unrestricted Cointegration Rank Test (Maximum Eigenvalue) } \\
\hline $\begin{array}{c}\text { Hypothesized } \\
\text { No. of CE(s) }\end{array}$ & Eigenvalue & $\begin{array}{l}\text { Max-Eigen } \\
\text { Statistic }\end{array}$ & $\begin{array}{c}0.05 \\
\text { Critical Value }\end{array}$ & Prob. ${ }^{\star *}$ \\
\hline None & 0.192052 & 11.08938 & 14.26460 & 0.1498 \\
\hline At most 1 * & 0.134212 & 7.493971 & 3.841466 & 0.0062 \\
\hline
\end{tabular}

Max-eigenvalue test indicates no cointegration at the 0.05 level

* denotes rejection of the hypothesis at the 0.05 level

${ }^{* *}$ MacKinnon-Haug-Michelis (1999) p-values

Unrestricted Cointegrating Coefficients (normalized by $b^{\prime *} S 11^{*} \mathrm{~b}=\mathrm{I}$ ):

\begin{tabular}{cc}
\hline \hline EXTERNAL_B... GDP_GROWTH_ANNUAL___ \\
-0.073307 & 0.592173 \\
0.324604 & -0.011917 \\
\hline \hline
\end{tabular}

Unrestricted Adjustment Coefficients (alpha):

\begin{tabular}{|c|c|c|c|}
\hline $\begin{array}{c}\text { D(EXTERNAL_... } \\
\text { D(GDP_GRO... }\end{array}$ & $\begin{array}{l}-0.037822 \\
-0.880586\end{array}$ & $\begin{array}{r}-0.846336 \\
0.166714\end{array}$ & \\
\hline \multicolumn{2}{|c|}{1 Cointegrating Equation(s): } & Log likelihood & -222.2912 \\
\hline \multicolumn{4}{|c|}{$\begin{array}{l}\text { Normalized cointegrating coefficients (standard error in parentheses } \\
\text { EXTERNAL_B...GDP_GROWTH__ANNUAL }\end{array}$} \\
\hline 1.000000 & $\begin{array}{r}-8.078012 \\
(2.32213)\end{array}$ & & \\
\hline \multicolumn{4}{|c|}{ Adjustment coefficients (standard error in parentheses) } \\
\hline D(EXTERNAL_... & $\begin{array}{l}0.002773 \\
(0.02446)\end{array}$ & & \\
\hline D(GDP_GRO... & $\begin{array}{l}0.064553 \\
(0.01971)\end{array}$ & & \\
\hline
\end{tabular}


Annex 6.

Autocorrelations with 2 Std.Err. Bounds

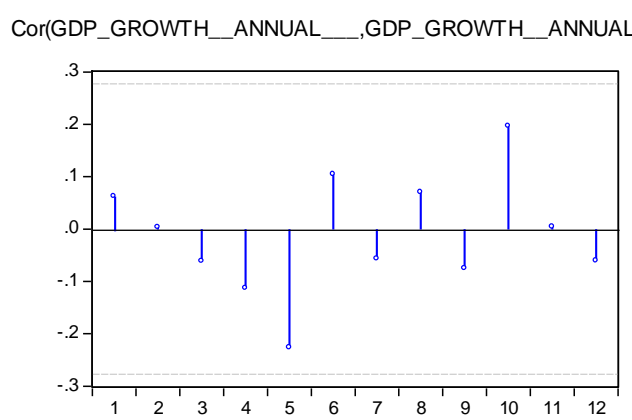

Cor(GDP_GROWTH_ANNUAL__EXTERNAL_BALANCE_ON_GOOD(-i))

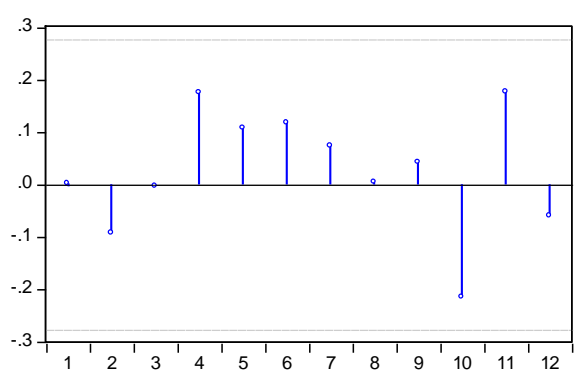

Cor(EXTERNAL_BALANCE_ON_GOOD,GDP_GROWTH_ANNUAL

(-i)) Cor(EXTERNAL_BALANCE_ON_GOOD,EXTERNAL_BALANCE_ON_GOOD(-i))
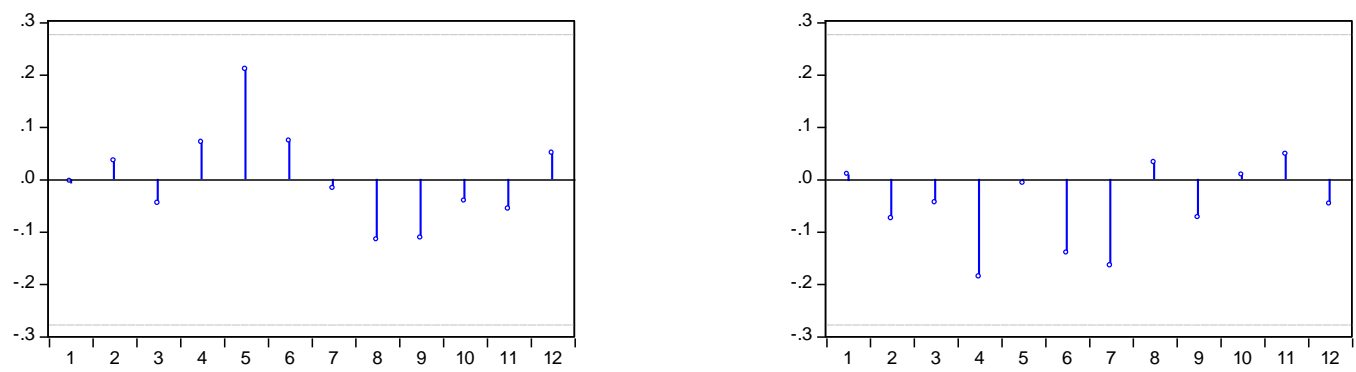


\section{Annex 7.}

VEC Residual Portmanteau Tests for Autocorrelations Null Hypothesis: no residual autocorrelations up to lag $h$ Date: 04/01/18 Time:21:12

Sample: 19632016

Included observations: 52

\begin{tabular}{cccccc}
\hline \hline Lags & Q-Stat & Prob. & Adj Q-Stat & Prob. & df \\
\hline \hline 1 & 0.223167 & NA $^{*}$ & 0.227543 & NA $^{*}$ & NA $^{*}$ \\
2 & 1.197123 & 0.9770 & 1.240457 & 0.9748 & 6 \\
3 & 1.798701 & 0.9977 & 1.878866 & 0.9972 & 10 \\
4 & 4.940950 & 0.9866 & 5.282970 & 0.9815 & 14 \\
5 & 9.335871 & 0.9514 & 10.14544 & 0.9271 & 18 \\
6 & 11.98166 & 0.9578 & 13.13633 & 0.9293 & 22 \\
7 & 13.80968 & 0.9754 & 15.24871 & 0.9526 & 26 \\
8 & 14.65538 & 0.9915 & 16.24817 & 0.9805 & 30 \\
9 & 16.38351 & 0.9953 & 18.33800 & 0.9869 & 34 \\
10 & 20.13271 & 0.9923 & 22.97987 & 0.9740 & 38 \\
11 & 22.30974 & 0.9946 & 25.74098 & 0.9772 & 42 \\
12 & 23.02905 & 0.9982 & 26.67608 & 0.9899 & 46 \\
13 & 40.60918 & 0.8257 & 50.11626 & 0.4688 & 50 \\
14 & 42.04856 & 0.8815 & 52.08593 & 0.5486 & 54 \\
15 & 45.72902 & 0.8786 & 57.25847 & 0.5028 & 58 \\
16 & 50.18609 & 0.8590 & 63.69646 & 0.4165 & 62 \\
17 & 54.35094 & 0.8465 & 69.88424 & 0.3485 & 66 \\
18 & 56.17175 & 0.8847 & 72.66900 & 0.3901 & 70 \\
19 & 57.50723 & 0.9216 & 74.77340 & 0.4530 & 74 \\
20 & 60.13647 & 0.9335 & 79.04591 & 0.4456 & 78 \\
\hline \hline
\end{tabular}

*The test is valid only for lags larger than the VAR lag order.

df is degrees of freedom for (approximate) chi-square distribution

\section{Annex 8.}

Roots of Characteristic Polynomial

Endogenous variables: GDP_GROWTH_ANNUAL_...

Exogenous variables:

Lag specification: 11

Date: 04/01/18 Time:21:08

\begin{tabular}{cc}
\hline \hline Root & Modulus \\
\hline \hline & \\
\hline .000000 & 1.000000 \\
0.570435 & 0.570435 \\
-0.300692 & 0.300692 \\
0.124127 & 0.124127 \\
\hline \hline
\end{tabular}

VEC specification imposes 1 unit root(s). 


\section{Annex 9.}

VEC Residual Normality Tests

Orthogonalization: Cholesky (Lutkepohl)

Null Hypothesis: residuals are multivariate normal

Date: 04/01/18 Time: 21:40

Sample: 19632016

Included observations: 52

\begin{tabular}{|c|c|c|c|c|}
\hline Component & Skewness & Chi-sq & $d f$ & Prob. \\
\hline 1 & 0.251083 & 0.546372 & 1 & 0.4598 \\
\hline 2 & -0.212071 & 0.389775 & 1 & 0.5324 \\
\hline Joint & & 0.936146 & 2 & 0.6262 \\
\hline Component & Kurtosis & Chi-sq & df & Prob. \\
\hline 1 & 3.585581 & 0.742962 & 1 & 0.3887 \\
\hline 2 & 3.463175 & 0.464818 & 1 & 0.4954 \\
\hline Joint & & 1.207780 & 2 & 0.5467 \\
\hline Component & Jarque-Bera & df & Prob. & \\
\hline 1 & 1.289334 & 2 & 0.5248 & \\
\hline 2 & 0.854592 & 2 & 0.6523 & \\
\hline Joint & 2.143926 & 4 & 0.7093 & \\
\hline
\end{tabular}




\section{Annex 10.}

VEC Residual Heteroskedasticity Tests: No Cross Terms (only levels and squares)

Date: 04/01/18 Time: $21: 41$

Sample: 19632016

Included observations: 52

Joint test:

\begin{tabular}{ccc}
\hline \hline Chi-sq & df & Prob. \\
\hline \hline 12.36673 & 18 & 0.8277 \\
\hline \hline
\end{tabular}

Individual components:

\begin{tabular}{cccccc}
\hline \hline Dependent & R-squared & $F(6,45)$ & Prob. & Chi-sq(6) & Prob. \\
\hline \hline res1*res1 & 0.102318 & 0.854856 & 0.5351 & 5.320557 & 0.5034 \\
res2*res2 & 0.063256 & 0.506456 & 0.8002 & 3.289308 & 0.7718 \\
res2*res1 & 0.099149 & 0.825458 & 0.5563 & 5.155728 & 0.5240 \\
\hline \hline
\end{tabular}

VEC Residual Heteroskedasticity Tests: Includes Cross Terms

Date: 04/01/18 Time:21:41

Sample: 19632016

Included observations: 52

Joint test:

\begin{tabular}{ccc}
\hline \hline Chi-sq & df & Prob. \\
\hline \hline 23.10345 & 27 & 0.6794 \\
\hline \hline
\end{tabular}

Individual components:

\begin{tabular}{cccccc}
\hline \hline Dependent & R-squared & $F(9,42)$ & Prob. & Chi-sq(9) & Prob. \\
\hline \hline res1*res1 & 0.124695 & 0.664805 & 0.7354 & 6.484115 & 0.6907 \\
res2*res2 & 0.092346 & 0.474793 & 0.8832 & 4.801987 & 0.8512 \\
res2*res1 & 0.204048 & 1.196334 & 0.3227 & 10.61050 & 0.3034 \\
\hline \hline
\end{tabular}

